\title{
Menstrual Disorders among Adolescent Females in Tala District, Menoufia Governorate, Egypt
}

\author{
Fatma A. El Esrigy MD ${ }^{1}$, Osama A. Al-Kelany MD², Marwa A.Al ShaikhMBBCh ${ }^{1 *}$ \\ ${ }^{1}$ Family Medicine Department, Faculty of Medicine, Menoufia University, Menoufia, Egypt. \\ ${ }^{2}$ Gynecology and obstetrics Department, Faculty of Medicine, Menoufia University Menoufia, \\ Egypt.
}

\begin{abstract}
Background: Menstrual disorders are common among adolescents and young adult women. These disorders actually may adversely affect the quality of the female' life and, therefore, considered a source of anxiety for them and their families. Objectives: The current study aimed to verify menstrual pattern, estimate the prevalence of menstrual disorders among adolescent females and study the interference of these disorders with social and physical life of the studied population. Methods This cross-sectional study was conducted on 300 adolescent females aged (14-18 years old) attended secondary schools in Tala district, Menoufia governorate, Egypt. Only females who had already menstruated were requested to participate. Socioeconomic status, Menstrual pattern, disorders and their interference with physical and social life were assessed through a predesigned questionnaire. Results: The current study revealed that the age of menarche of the studied adolescent females was between 9 and 16 years and the prevalence of menstrual disorders was $87 \%$. There was statistically significant relationship between the menstrual disorders in adolescent females, socioeconomic standard and family history of menstrual disorders ( $\mathrm{p}$ value $<0.05$ ). Moreover, adolescent females with menstrual disorders showed significant higher prevalence of school abstinence and significant worsening of pre-menstrual tension symptoms than girls without menstrual disorders.
\end{abstract}

Conclusion This study concluded that the prevalence of menstrual disorders among the studied adolescent females was $(87 \%)$. Dysmenorrhea was the most prevalent menstrual disorders in adolescence females followed by menorrhagia and these disorders usually responsible for their school absenteeism, and worsening of premenstrual tension symptoms.

Keywords: Adolescent, Dysmenorrhea, Menarche, Menstrual disorder, School absenteeism, Menorrhagia.

\begin{tabular}{ll}
\hline $\begin{array}{l}\text { Introduction: } \\
\text { Menstrual problems are major }\end{array}$ & $\begin{array}{l}\text { oligo menorrhea. }{ }^{(2)} \text { These disorders } \\
\text { are common during the first two years }\end{array}$ \\
gynecological problems, especially & after menarche and the variability in \\
among adolescent females. These & cycle length is greater during \\
disorders can often cause an anxiety & adolescence than adulthood. ${ }^{(3)}$ These \\
for female adolescents and their & menstrual irregularities can be related \\
families. ${ }^{(1)} \quad$ They include, & to the incomplete maturation of \\
dysmenorrhea, & Hypothalamic-pituitary-ovarian axis \\
syndrome, menorrhagia, amenorrhea, & which may take more than two years
\end{tabular}

*Corresponding author: E-mail: efatmaahmed@yahoo.com 
after menarche until complete maturation. $^{(4)}$ Most common menstrual problem during adolescence is dysmenorrhea. ${ }^{(5)}$

It is suggested that these disorders may be related to different variables as diet and eating disorders, exercise and body mass index (BMI), stress and chronic diseases. ${ }^{(6)}$ Which can lead to a variety of psychological problems among the adolescents as anxiety and depression particularly with limited awareness related to this topic. ${ }^{(4)}$

Moreover, menstrual pain and symptoms cause school absence for teenagers, they also interfere with life activities. ${ }^{(7)}$ As a result of the overlap between dysmenorrhea, PMS and some endometriosis symptoms there is difficulty to distinguish normal pain and PMS from pathological disease ${ }^{(8)}$ Menstrual history forms an important domain of adolescent health and because most of menstrual problems go unreported, it is necessary to provide adequate attention and care to protect against the long-term consequences on reproductive and sexual health. ${ }^{(8)}$

The current study aimed to verify menstrual pattern, estimate the prevalence of menstrual disorders among adolescent females and study the interference of these disorders with social and physical life of the studied population.

\section{Methods:}

This cross sectional study was conducted on 300 secondary school females aged between 14 and 18 years old from May 2017 to October 2019, in the only two secondary schools in Tala district (one urban and one rural), Menoufia Governorate, Egypt. Tala district was selected by multistage stratified random sampling from districts affiliated to Menoufia governorate (13 districts).

The sample size was calculated using online Rao soft program based on the prevalence of menstrual disorders among adolescent females $81 \%{ }^{[9]}$ at $95 \%$ confidence interval, the calculated sample size was calculated, it was 293 and increased to 300 to round the figure. The sample was proportionally allocated according to the total number of student females in each school.

From the two schools all grades were selected. Each grade of the secondary school contains two classes, one class from each grade was selected randomly, and the average number of each class was 50 
adolescent females. Pilot study was done, to measure feasibility of study setting, content and validity of the used tools, on a convenient sample of twenty accepted subjects and were excluded from the study. Adolescent females who were non cooperative, had any chronic medical, neurological disorders and with regular medication were excluded from the study.

All participants were subjected to face to face interview to answer a predesigned questionnaire. Only females who had already menstruated were requested to participate. They were instructed not to write their names on the questionnaire and were told that their responses would be confidential. The questionnaire consisted of three sections: socio-demographic data according to Fahmy et al. ${ }^{(10)}$

Details of the menstrual history in the questionnaire included; age at menarche, menstrual cycle length and regularity, duration and amount of flow, type and severity of pain related to menstruation; and need for analgesia. They were asked to indicate the severity of pain on a scale from 0 to $10(0-3=$ no/mild pain, $4-$ $7=$ moderate pain, and $8-10=$ severe pain).
Symptoms suggestive of PMS were included in the questionnaire so that the students could check those relevant to them. Menstrual cycle patterns were defined as follows; regular menstrual cycles: cycle length of 21-35days, irregular menstrual cycles: varying cycle length less than 21 or more than 35 days, secondary amenorrhea: having missed $\geq 3$ consecutive cycles in the last 12 months, prolonged menstrual flow (menstrual flow of more than 7 days), and hypo menorrhea (menstrual flow less than 2 days), Assessment of medical history and family history of menstrual disorders. Respondents were also asked about the impact of menstruation and its disorders on their school attendance and social life according to parker et al. ${ }^{(11)}$

The questionnaire was accepted to be used since it was translated into the Arabic language. The translated questionnaire was revised by a panel of three expertise to test its validity.

Ethical Consideration: The study was approved by the Ethical Committee of the Faculty of Medicine, Menoufia University. Administrative per missions were obtained from authority of faculty of Medicine. Verbal consent was 
obtained from all participants with their assurance regarding the confidentiality of the obtained information.

Statistical Analysis: Data were analyzed using Statistical package of Social Science (SPSS) version 23 (using IBM personal computer). Quantitative data (age) were expressed as mean and standard deviations $(\mathrm{X} \pm \mathrm{SD})$ and analyzed by student t test. Qualitative data were expressed as number and percentage and analyzed by applying Chi-square test.

\section{Results:}

The prevalence of menstrual disorders among the studied adolescent females was $87 \%$ (Figure 1). The age of menarche of the studied sample was between 9 and 16 years with a mean of $12.6 \pm 1.4$. The range of menstrual cycle length was 23-35 days with a mean of 29.31 2.114 (Table 1). There was statistically significant relationship between the menstrual disorders in adolescent females, socioeconomic standard and family history of menstrual disorders ( $\mathrm{p}$ value $<0.05$ ), as most of the participants with low socioeconomic standard (95\%) and with family history of menstrual disorders (88\%) had menstrual disorders. (Table 2).

There was statistically significantly relation between the presence of menstrual disorders, school absence and Worsening Premenstrual tension symptoms as most of participants with menstrual disorders reported absence from school $(80.5 \%)$ and about two third of them suffered from worsening premenstrual tension symptoms (65\%), (Table 3).

\section{Discussion:}

This cross sectional (analytical) study recruited adolescent females aged from 14 to18 years old with mean age of menarche $12.6 \pm 1.4$ years .This result is consistent with Tayebi et al. ${ }^{(12)}$ who performed a crosssectional study on girls aged between 9 and 18 years old in Shiraz city (Iran) and found that the age of menarche was was12.26 \pm 1.11 years. This is inconsistent with Zegeye et al., ${ }^{(4)}$ in a study from northwest Ethiopia reported a delayed age at menarche was (15.8 \pm 1 years). These variations in the age of menarche may be attributed to environmental and genetic factors or difference in body mass index of the studied group. 
The current study showed that majority of the studied participants $(87 \%)$ suffered from one or more menstrual disorders the commonest is dysmenorrhea $(62.75 \%)$ followed by menorrhagia (45\%). This result is in agreement with Abdelmoty et al. ${ }^{(13)}$ who performed a cross-sectional survey on Egyptian adolescents and reported that the prevalence rate of menstrual disorders was $95 \%$. This is in the same line with Karout et al. ${ }^{(14)}$ who reported that nearly half of the girls reported menorrhagia. This is in agreement with Negi et al. ${ }^{(15)}$ who also detected that dysmenorrhea was one of the commonest menstrual problem among adolescent Indian girls. Besides, El-Gilany et al. ${ }^{(16)}$ reported higher prevalence of dysmenorrhea among Egyptian teenagers for the same age group $(80 \%)$. The differences in results were related to the degree of pain severity may be related to cultural differences in pain perception, absence of a universally accepted method of defining dysmenorrhea and individual variability in pain threshold. ${ }^{(16)}$

This study denoted that the menstrual disorders were statistically correlated with low socioeconomic standard and family history of menstrual disorders. This is consistent with Valvaikar et al. (17) who revealed that; the presence of menstrual disorders was significantly correlated with low socioeconomic levels and family history of menstrual disorder.

The current study denoted that menstrual disorders were found to be greatly affecting social life of the studied group. Adolescent females with menstrual disorders showed significant higher prevalence of school abstinence and significant worsening of pre-menstrual tension symptoms than girls without menstrual disorders. This in agreement with Beevi et al. ${ }^{(18)}$ who reported the affection of their daily life activities by the menstrual disorders. Could not attend the class and attended the class without taking medication but could not participate in any outdoor activities.

Hillen et al. ${ }^{(19)}$ found that $53 \%$ of girls with dysmenorrhea reported interference and/or limitation of activities, $48 \%$ on sporting activities, $46 \%$ social activities, $45 \%$ said their school activities were limited and $18 \%$ reported interference longer than 48 hours. 
Conclusions: This study concluded that the prevalence of menstrual disorders among the studied adolescent females was $(87 \%)$. The commonest disorder was: Dysmenorrhea was the most prevalent menstrual disorders in adolescence females followed by Menorrhagia and these disorders usually responsible for their school absenteeism and pre-menstrual tension symptoms. So it is important for the clinicians to the skills to differentiate between normal and pathological menstrual patterns and timeline referral of cases that necessitate further investigations and evaluation.

Study limitation: The current study was a cross section and data collection depends on participant recall that may lead to recall bias. Moreover, menstrual and gynecological problems are embarrassing issue for adolescents' females.

Conflict of interest: There was no conflict of interest and there were no funding agencies.

Acknowledgment: The author gratefully acknowledges the support from head manager of the selected FMU

\section{References:}

1. Titilayo A, Agunbiade OM, Banjo $\mathrm{O}$ et al. Menstrual discomfort and its influence on daily academic activities and psychosocial relationship among undergraduate female students in Nigeria. TJHR. 2009; 11(4):22-27

2. Greydanus DE, Sorrel S, Omar $\mathrm{HA}$ et al. Adolescent female menstrual disorders. IJCAH. 2012; 5(4):357.

3. Chhabra S, Venkatraman S. Menstrual dysfunction in rural young women and the presence of polycystic ovarian syndrome. Journal of Obstetrics and Gynaecology. 2010; 30(1):41-5.

4. Zegeye DT, Megabiaw B, Mulu A. Age at menarche and the menstrual pattern of secondary school adolescents in northwest Ethiopia. BMC women's health. 2009; 9(1): 23-29.

5. Amu EO, Bamidele JO. Prevalence of menstrual disorders among adolescent girls in Osogbo, South Western Nigeria. Int $\mathbf{J}$ Adolesc Med Health. 2014; 26:101-106.

6. Patavegar BN, Rasheed NA, Pathak RA et al. Menstrual 
pattern and menstrual disorders among school going adolescent girls in Delhi. J Applied Basic Res Int. $2015 ; 11: 241-6$.

7. American Academy of Pediatrics, American College of Obstetricians and Gynecologists: Menstruation in girls and adolescents: using the menstrual cycle as a vital sign. Pediatrics. 2006; 118(5):2245-50.

8. American College of Obstetricians and Gynecologists. ACOG committee opinion No. 310, April 2005. Endometriosis in adolescents. Obstet Gynecol 2005; 105:921-7.

9. Franco Rigon, Vincenzo De Sanctis, Sergio Bernasconi et al. Menstrual pattern and menstrual disorders among adolescents .an updated of Italian data. Ital $\mathbf{J}$ Pediatr. 2012; 38: 38.

10. Fahmy SI, Nofal LM, Shehata SF et al. Updating indicators for scaling the socioeconomic level of families for health research. JEPHA. 2015; 90(1):1-7.

11. Parker MA, Sneddon AE, Arbon P. The menstrual disorder of teenagers (MDOT) study: determining typical menstrual patterns and menstrual disturbance in a large populationbased study of Australian teenagers. BJOG. 2010; 117:185192.

12. Tayebi N, Yazdznpanahi Z, Yektatalab S et al. Pattern of menarche age and its relationship with some demographic characteristics in girls and their parents. Int $\mathbf{J}$ Adolesc Med Health. 2016; 30(3): 1-7.

13. Abdelmoty HI, Youssef MA, Abdel-Malak K et al. Menstrual patterns and disorders among secondary school adolescents in Egypt. A cross-sectional survey. BMC women's health. 2015; 15(1):1-6

14. Karout N, Hawai SM, Altuwaijri S. Prevalence and pattern of menstrual disorders. East Mediterr Health J. 2012;18(4):346-52.

15. Negi P, Mishra A, Lakhera P. Menstrual abnormalities and their association with lifestyle pattern in adolescent girls of Garhwal, India. J Family Med Prim Care. 2018;7(4):804-808.

16. El-Gilany AH, Badawi K, ElFedawy S. Epidemiology of dysmenorrhea among adolescent students in Mansoura. Egypt East 
Mediterr Health J. 2005; 11(12):155-63.

17. Valvaikar KS, Shah HK. An urban-rural comparison of menstrual pattern and menstrual problems among school-going girls. Int J Med Sci Public Health. 2016; 5(10):2086-91.

18. Beevi N, Manju L, Haran JC, Jose R. Menstrual problems among adolescent girls in
Thiruvananthapuram district. IJCMPH. 2017; 4(8):2995-8.

19.

20. Hillen TI, Grbavac SL, Johnston $\mathrm{PJ}$ et al. Primary dysmenorrhea in young Western Australian women: prevalence, impact, and knowledge of treatment. $\mathrm{J}$ of adolesc. health. 1999; 25(1):40-5. 


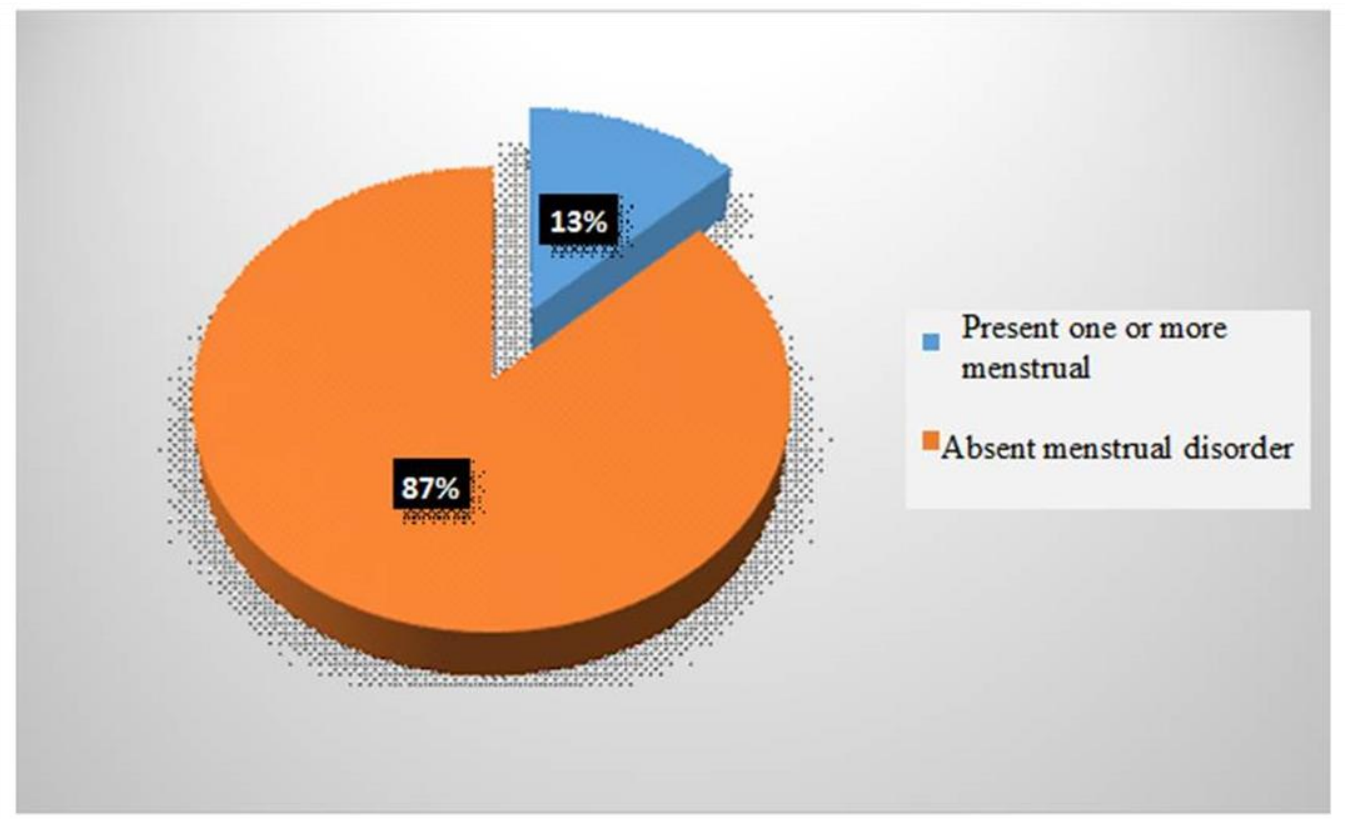

Figure (1): Frequency of menstrual disorders among the studied participants

Table (1): Menstrual pattern and disorders among the studied participants

\begin{tabular}{|c|c|c|}
\hline Parameter & No. (300) & $\%$ \\
\hline $\begin{array}{l}\text { Menarche } \\
\text { - Mean } \pm \text { SD } \\
\text { - Range }\end{array}$ & \multicolumn{2}{|c|}{$\begin{array}{c}12.6 \pm 1.4 \\
(9-16) \text { years }\end{array}$} \\
\hline $\begin{array}{l}\text { Regularity of menstrual bleeding } \\
\text { - Regular } \\
\text { - Irregular }\end{array}$ & $\begin{array}{l}112 \\
188\end{array}$ & $\begin{array}{l}37.3 \\
62.6\end{array}$ \\
\hline $\begin{array}{c}\text { Length of menstrual cycle } \\
\text { - Irregular } \\
\text { - Regular }\end{array}$ & $\begin{array}{l}188 \\
112\end{array}$ & $\begin{array}{l}62.7 \\
37.3\end{array}$ \\
\hline $\begin{array}{l}\text { - Mean } \pm \text { SD } \\
\text { - Range }\end{array}$ & \multicolumn{2}{|c|}{$\begin{array}{c}29.31 \pm 2.114 \\
(23-35)\end{array}$} \\
\hline $\begin{array}{c}\text { Dysmenorrhea } \\
\text { - Yes } \\
\text { - No }\end{array}$ & $\begin{array}{l}191 \\
109\end{array}$ & $\begin{array}{l}63.7 \\
36.3\end{array}$ \\
\hline $\begin{array}{l}\text { Presence of blood clot } \\
\text { - Yes } \\
\text { - No }\end{array}$ & $\begin{array}{l}167 \\
133\end{array}$ & $\begin{array}{l}55.7 \\
44.3\end{array}$ \\
\hline $\begin{array}{c}\text { Intermenstrual bleeding } \\
\text { - Yes } \\
\text { - No }\end{array}$ & $\begin{array}{c}96 \\
204\end{array}$ & $\begin{array}{l}32.0 \\
68.0\end{array}$ \\
\hline $\begin{array}{c}\text { Menorrhagia* } \\
\text { - Yes } \\
\text { - No }\end{array}$ & $\begin{array}{l}135 \\
165\end{array}$ & $\begin{array}{c}45.0 \\
55.0^{*}\end{array}$ \\
\hline
\end{tabular}

* Menorrhagia is defined as regular cycle with excessive flow and duration. 
Table (2): Relation between menstrual disorders, socio demographic characteristic and medical history of the studied group

\begin{tabular}{|c|c|c|c|c|c|c|}
\hline \multirow[t]{3}{*}{ Items } & \multicolumn{6}{|c|}{ Menstrual disorder } \\
\hline & \multicolumn{2}{|c|}{ Absent } & \multicolumn{2}{|c|}{ Present } & \multirow[t]{2}{*}{$\mathrm{X}^{2}$} & \multirow[t]{2}{*}{ P-value } \\
\hline & $\begin{array}{l}\text { No. } \\
39\end{array}$ & $\begin{array}{l}\% \\
13 \\
\end{array}$ & $\begin{array}{l}\text { No. } \\
261\end{array}$ & $\begin{array}{l}\% \\
87 \\
\end{array}$ & & \\
\hline $\begin{array}{l}\text { Age } \\
\text {. Mean } \pm \text { SD }\end{array}$ & \multicolumn{2}{|c|}{$16.77 \pm 0.872$} & \multicolumn{2}{|c|}{$16.56 \pm .933$} & $1.297 *$ & 0.196 \\
\hline $\begin{array}{l}\text { Menarche } \\
\quad \quad \text { Mean } \pm \text { SD }\end{array}$ & \multicolumn{2}{|c|}{$12.18 \pm 1.393$} & \multicolumn{2}{|c|}{$12.72 \pm 1.365$} & $-2.301 *$ & 0.849 \\
\hline $\begin{aligned} & \text { BMI } \\
& \text { - Under weight } \\
& \text { - } \text { Average } \\
& \text { - Overweight } \\
&\end{aligned}$ & $\begin{array}{c}3 \\
27 \\
7 \\
2 \\
\end{array}$ & $\begin{array}{c}17.6 \\
14.9 \\
8.3 \\
11.1 \\
\end{array}$ & $\begin{array}{c}14 \\
154 \\
77 \\
16 \\
\end{array}$ & $\begin{array}{l}82.4 \\
85.1 \\
91.7 \\
88.9\end{array}$ & 2.587 & 0.46 \\
\hline $\begin{array}{c}\text { Residence } \\
\text { - Urban } \\
\text { - Rural }\end{array}$ & $\begin{array}{l}14 \\
25\end{array}$ & $\begin{array}{l}10.6 \\
14.9\end{array}$ & $\begin{array}{l}118 \\
143\end{array}$ & $\begin{array}{l}89.4 \\
85.1\end{array}$ & 1.194 & 0.179 \\
\hline $\begin{array}{l}\text { Socioeconomic } \\
\text { status } \\
\text { - Low } \\
\text { - Middle } \\
\text { - High }\end{array}$ & $\begin{array}{c}1 \\
11 \\
27\end{array}$ & $\begin{array}{c}5 \\
8.3 \\
18.2\end{array}$ & $\begin{array}{c}19 \\
121 \\
121\end{array}$ & $\begin{array}{c}95 \\
91.7 \\
81.8\end{array}$ & 7.271 & 0.026 \\
\hline $\begin{array}{l}\text { Family history of } \\
\text { menstrual disorder } \\
\text { - Yes } \\
\text { - No } \\
\text { - Don't know }\end{array}$ & $\begin{array}{c}19 \\
14 \\
6\end{array}$ & $\begin{array}{c}11.2 \\
24.6 \\
8.1\end{array}$ & $\begin{array}{c}150 \\
43 \\
68\end{array}$ & $\begin{array}{l}88.8 \\
75.4 \\
91.9\end{array}$ & 8.764 & 0.013 \\
\hline
\end{tabular}

BMI: Body Mass Index

SD: stander deviation

$\mathrm{X}^{2}$ : chi-square $*$ student $t$ test 
Table (3): Interference of menstrual disorders on social and physical life of studied participants

\begin{tabular}{|c|c|c|c|c|c|c|}
\hline \multirow{3}{*}{ Parameter } & \multicolumn{4}{|c|}{ Menstrual disorders } & \multirow[t]{3}{*}{$\mathrm{X}^{2}$} & \multirow[t]{3}{*}{ P-value } \\
\hline & \multicolumn{2}{|c|}{ Absent } & \multicolumn{2}{|c|}{ Present } & & \\
\hline & $\begin{array}{l}\text { No } \\
40\end{array}$ & $\%$ & $\begin{array}{l}\text { No } \\
260\end{array}$ & $\%$ & & \\
\hline $\begin{array}{c}\text { School abstinence } \\
\text { - Yes } \\
\text { - No }\end{array}$ & $\begin{array}{l}25 \\
15\end{array}$ & $\begin{array}{l}62.5 \\
37.5\end{array}$ & $\begin{array}{c}209 \\
51\end{array}$ & $\begin{array}{l}80.4 \\
19.5\end{array}$ & 12.4 & 0.001 \\
\hline 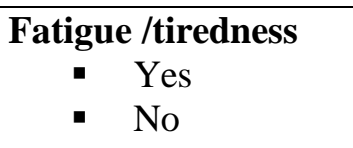 & $\begin{array}{l}29 \\
11\end{array}$ & $\begin{array}{l}72.5 \\
27.5\end{array}$ & $\begin{array}{l}151 \\
109\end{array}$ & $\begin{array}{l}58.1 \\
41.9\end{array}$ & 3.005 & 0.057 \\
\hline $\begin{array}{c}\text { Loss of appetite } \\
\text { - Yes } \\
\text { - No }\end{array}$ & $\begin{array}{l}26 \\
14\end{array}$ & $\begin{array}{l}65.0 \\
35.0\end{array}$ & $\begin{array}{l}137 \\
123\end{array}$ & $\begin{array}{l}52.7 \\
47.3\end{array}$ & 2.116 & 0.174 \\
\hline $\begin{array}{c}\text { Analgesic abuse } \\
\text { - Yes } \\
\text { - No } \\
\text { - } \text { Don't use }\end{array}$ & $\begin{array}{c}20 \\
3 \\
17\end{array}$ & $\begin{array}{c}50.0 \\
7.5 \\
42.5\end{array}$ & $\begin{array}{c}171 \\
10 \\
79\end{array}$ & $\begin{array}{c}65.8 \\
3.8 \\
30.4\end{array}$ & 4.012 & 0.135 \\
\hline $\begin{array}{c}\text { Mood swings } \\
\text { - } \quad \text { Yes } \\
\text { - } \quad \mathrm{No}\end{array}$ & $\begin{array}{l}25 \\
15\end{array}$ & $\begin{array}{l}62.5 \\
37.5\end{array}$ & $\begin{array}{l}159 \\
101\end{array}$ & $\begin{array}{l}61.2 \\
38.8\end{array}$ & 0.026 & 0.509 \\
\hline $\begin{array}{c}\text { Worsening of PMTS } \\
\text { - Yes } \\
\text { - No }\end{array}$ & $\begin{array}{l}18 \\
22\end{array}$ & $\begin{array}{l}45.0 \\
55.0\end{array}$ & $\begin{array}{c}169 \\
91\end{array}$ & $\begin{array}{l}65.0 \\
35.0\end{array}$ & 5.906 & 0.013 \\
\hline
\end{tabular}

$\mathrm{X}^{2}$ : chi-square

PMTS: Premenstrual Tension Symptoms 


\section{الملخص العربي}

اضطرابات الحيض بين المراهقات في مركز تلا- محافظة المنوفية_مصر

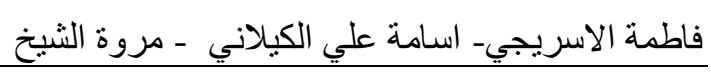

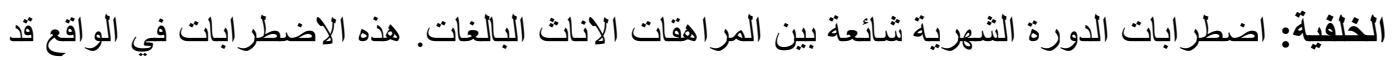

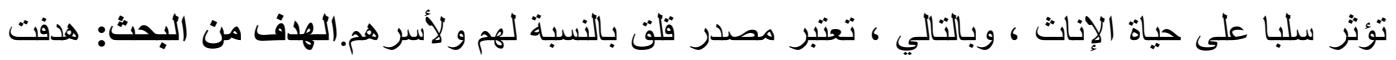

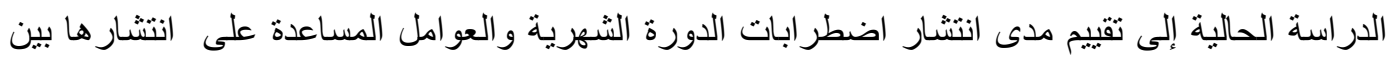
المر اهقات المصريات. المنهجية و طرق البحث: أجريت دراسة تحليلية مقطعية على 300 من الاناث

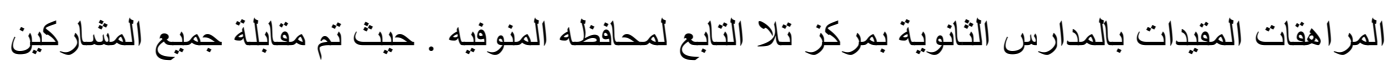

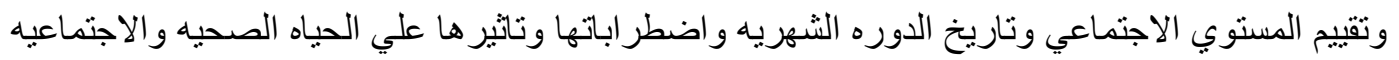
من خلال استبيان مصمم مسبقًا. النتائج : اظهرت نتائج الدر اسة ان منوسط العمر عند الحيض 12.65 ـ 12.379 سنة فئ المجموعة العمرية

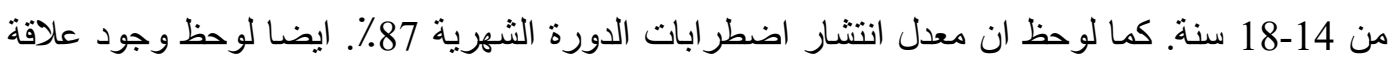

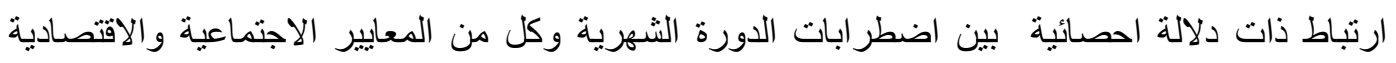

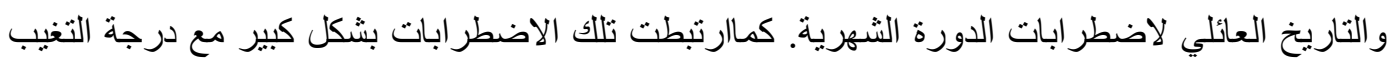

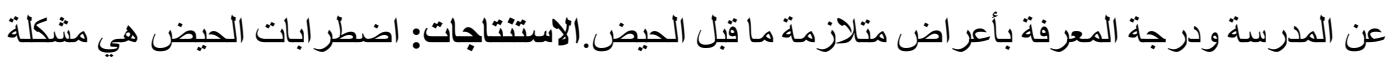

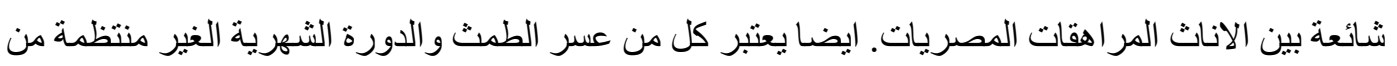

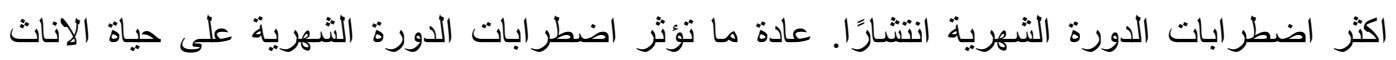

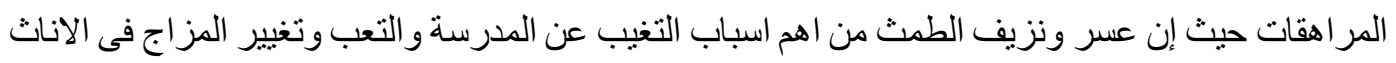
المر اهقات فى مصر. 